\title{
Against a regular epenthesis rule for Hmong-Mien
}

\author{
MARTHA RATLIFF \\ Wayne State University
}

\begin{abstract}
${ }^{*}$ mbl-/*mbr- (Ratliff 2010) and ${ }^{*}$ m.l(y)-/*m.r(y)- (Ostapirat 2016) have been proposed as reconstructions for correspondence sets that include NCL-, CL-, $\mathrm{N}-$, and $\mathrm{C}$ - onsets across the Hmong-Mien family. Ostapirat assumes that the stop arose by a regular rule of epenthesis in the protolanguage. I examine the arguments for these two reconstructions and conclude that epenthesis in an onset is not without cross-linguistic support, but it is not the better analysis in this case. The arguments against a regular epenthesis rule for Hmong-Mien are based primarily on laryngeal contrasts in stops occurring in this position and the relationship of NCL- onsets to Proto-Hmong-Mien prenasalized stops. Secondary arguments involve exceptions to an epenthesis rule, and a reconsideration of the loanword evidence.
\end{abstract}

\section{Introduction}

*mbl-/*mbr- (Ratliff 2010) and *m.l(y)-/*m.r(y)- (Ostapirat 2016) have been proposed as reconstructions for correspondence sets that include NCL-, CL-, N-, and C- onsets across the Hmong-Mien family, as exemplified by words with medial -l- in the following table (Chen 2013). ${ }^{1}$

\begin{tabular}{|c|c|c|c|c|}
\hline & tongue & rice & leech & leaf \\
\hline Gaozhai H & mblæD & mblei $^{\mathrm{A}}$ & mblei $^{\mathrm{B}}$ & mblon $^{A}$ \\
\hline Dananshan $\mathrm{H}$ & mplai ${ }^{8}$ & mple $^{2}$ & - & mplon $^{2}$ \\
\hline Zongdi $\mathrm{H}$ & mple $^{8}$ & mplæ ${ }^{2}$ & $\mathrm{mpl}^{4}$ & mplan $^{2}$ \\
\hline Shimenkan H & ndlfai ${ }^{8}$ & ndlfi ${ }^{2}$ & ndlfa $^{4}$ & ndlfau ${ }^{2}$ \\
\hline Yanghao H & $\mathrm{ni}^{8}$ & na $^{2}$ & njin 4 & nә ${ }^{2}$ \\
\hline Younuo $\mathrm{H}$ & $\mathrm{mi}^{8}$ & mjau $^{2}$ & $\mathrm{mi}^{4}$ & mjon $^{2}$ \\
\hline Xiashuicun H & $\mathrm{pi}^{8}$ & pja $^{2}$ & - & pjon $^{2}$ \\
\hline Longhua H & $\mathrm{mpli}^{8}$ & mpla $^{2}$ & 一 & mplpn $^{2}$ \\
\hline Longding $\mathrm{M}$ & bjet $^{8}$ & $\mathrm{bau}^{2}$ & 一 & 一 \\
\hline Yanyuan M & bjat $^{8}$ & blau $^{2}$ & 一 & - \\
\hline Youling M & bet $^{8}$ & $\mathrm{bu}^{2}$ & $\operatorname{bin}^{4}$ & 一 \\
\hline
\end{tabular}

\footnotetext{
${ }^{1}$ Ostapirat 2016 is a paper that focuses on the reconstruction of velarization to account for a number of difficult correspondences in Hmong-Mien; the reconstruction of NL- onsets and an epenthesis rule is a secondary point raised in the context of this larger issue.
} 
Ostapirat's reconstruction of *m.l( $\mathrm{\gamma})$ - and ${ }^{*} \mathrm{~m} . \mathrm{r}^{(\mathrm{\gamma})}$ - assumes that the stop arose by a regular rule of epenthesis in the protolanguage. ${ }^{2} \mathrm{His}$ proposal is supported by evidence from Chinese loanwords that fall into this correspondence set: most clearly, the word for 'tongue' (Proto$\mathrm{HM}^{3}$ *mblet; Old Chinese 舌 *molat > Mandarin shé), and more controversially, as will be discussed in section 4.4 .1 below, the word for 'rice' (Proto-HM *mbleu 'rice plant; unhusked rice'; Old Chinese 稻 *[1] $]^{\varsigma} u$ ? 'rice; paddy' > Mandarin dào). Although correspondence sets with NCL- reflexes at other places of articulation are not addressed in Ostapirat's 2016 paper, I assume that he would treat all such correspondences the same way.

The purpose of this paper is to examine the arguments for these two reconstructions, a matter that will chiefly concern Asianists, and to address the likelihood of a regular rule of epenthesis in an onset, a matter that may be of interest to the larger community of historical linguists. My conclusion is that epenthesis in an onset is not without cross-linguistic support, but it is not the better analysis here. The arguments against a regular rule of epenthesis for Hmong-Mien are based primarily on otherwise inexplicable laryngeal contrasts in stops that occur in this position and on the relationship of these onsets to Proto-Hmong-Mien prenasalized stops. Secondary arguments involve exceptions to an epenthesis rule, and a reconsideration of the loanword evidence.

\section{Epenthesis between nasal and liquid as a regular sound change}

Phonetically, stop epenthesis between two consonants is the consequence of mis-timing of articulatory gestures: the velic closure of the nasal is released before the oral closure of the nasal, producing a stop at the same place of articulation as the nasal (Picard 1987, Ohala 1997, Warner \& Weber 2001, Recasens 2011). Between a nasal and an obstruent (hamster $\rightarrow$ hampster) the emergence of the stop is due in

\footnotetext{
2 The term 'excrescence' would be more precise to refer to the emergence of a stop between a nasal and a liquid; moreover, it captures the nature of a change in which the emerging stop manifests features already present within the earlier *NL- cluster. The term 'emergent stops' (Ohala 1997) would also be preferable to 'epenthesis' for the same reason. However, I defer to common usage in referring to the sound change as 'epenthesis' here.

3 The abbreviations used in this paper are as follows: NCL- = a nasal-consonant-liquid onset; CL- = a (non-nasal) consonant-liquid onset; $\mathrm{N}-=$ a nasal-only onset; $\mathrm{C}-=\mathrm{a}$ (nonnasal) consonant-only onset; superscript letters and numbers, as in the forms in the table on the previous page and in (3), refer to historical tone categories A (1 \& 2 following the tone split that occurred in most languages), B (3 \& 4), C (5 \& 6), D (7 \& 8); language family abbreviations are: CEMP = Central-Eastern Malayo-Polynesian; $\mathrm{H}$ =Hmongic; $\mathrm{HM}$ = Hmong-Mien; $\mathrm{M}$ = Mienic; WMP = Western Malayo-Polynesian.
} 
part to the buildup of pressure required for the anticipated production of the obstruent. Between a nasal and a liquid, however, the pressure buildup is weaker. Stops may emerge here for a perceptual rather than an articulatory reason: a nasalized liquid in a nasal-liquid cluster is less recognizable as an /l/ or an / $\mathrm{r} /$; an emergent stop serves to keep them distinct (Ohala 1997, 3). In either type of cluster the voicing of the epenthetic stop continues the voicing of one or both of the flanking consonants: in nasal-liquid clusters, given that both consonants are voiced, emergent stops are overwhelmingly voiced as well.4

Compared to other assimilatory spreading rules, "Historical change involving epenthetic stops is relatively rare and sporadic ..." (Warner \& Weber 2001, 81). Since stop epenthesis between consonants involves the common assimilatory sound changes of place and voicing feature spreading, one might expect it to occur across languages more frequently than it does. Its relative scarcity is likely due to a combination of factors: (i) the necessary input clusters do not exist in some languages; (ii) the complex output clusters may violate phonotactic rules in some languages; and (iii) unlike other kinds of assimilation or mis-timing sound changes, the insertion of a stop involves a significant structural complication: the addition of a slot on the skeletal tier (or a violation of the DEP-IO constraint, however one prefers to look at it). And even though they may produce a stop in this environment, literate speakers may also be influenced by their knowledge that the word is written without a stop.

The question of whether or not such sound changes are sporadic, as well as uncommon, goes to the heart of the Hmong-Mien reconstruction problem. This question was addressed in Picard 1989. Picard's view is that consonant epenthesis may be regular, but only if the rules paraphrased in (1) are followed.

(1) Rule I The epenthetic stop agrees in place of articulation with $\mathrm{C} 1$, and is voiced only if both $\mathrm{C} 1$ and $\mathrm{C} 2$ are voiced.

Rule II There are only two types of stop epenthesis:

- Type I: after nasal, liquid, or fricative \& before liquid

- Type II: after nasal or liquid \& before stop or fricative

Rule III Type I epenthesis can only occur when a syllable boundary falls between C1 and C2; the stop is inserted to the right of boundary (e.g., m.l > m.bl)

Rule IV Type I epenthesis can only yield a permissible onset (so m.bl is possible only if bl- occurs as syllable onset elsewhere)

\footnotetext{
${ }^{4}$ I call this Rule I below; rare exceptions like exemplum and templum exist, however.
} 
Picard considers other types of consonant epenthesis within a consonant cluster such as -sl- > -skl- "sporadic", because they violate one or more of these rules (in this case, the first part of Rule I).

As we will see below, the problem in applying Picard's rules to the Hmong-Mien case, if this case does indeed involve a regular rule of epenthesis, is that both Rules I and III are violated. I will address the Rule III violation first, since it appears to follow from the IndoEuropean examples that Picard was considering. A set of examples drawn from a more diverse set of languages may require a modification of this particular rule, in which case the epenthesis analysis is safe. The Rule I violations, on the other hand, pose a serious problem for the epenthesis analysis (discussed in sections 4.1 and 4.2).

\subsection{NL-epenthesis in medial position}

The most frequently cited cases of stop epenthesis between a nasal and a liquid come from Indo-European medial NL clusters; they are the examples upon which Picard's rules are based. Examples include those in (2).

\section{(2)}

$\begin{array}{ll}\text { English } & \\ \text { thymel } & >\text { thim.ble } \\ \text { nemel } & >\text { nim.ble } \\ \text { thuner } & >\text { thun.der } \\ & \\ \text { French } & \\ \text { sim(i)lāre } & >\text { sem.bler } \\ \text { cam(e)ra } & >\text { cham.bre } \\ \text { num(e)rum } & >\text { nom.bre }\end{array}$

In these words the nasal and liquid are in word-medial position. Picard's Rule III holds that a syllable break will fall between the nasal and the epenthetic stop (and Rule IV holds that the stop-liquid cluster so created will be an acceptable syllable onset in the language). Another force that may govern the emergence of a stop in medial position is the drive to 'repair' the sonority contour between syllables when the first ends in a nasal which is less sonorous than the liquid that opens the second. In such cases, the word-medial -m.l- has a rising sonority slope from coda to onset, whereas -m.bl- has the universally preferred falling sonority slope from coda to onset (Recasens 2011, 1139).

In languages with monosyllabic morphemes, and, for the most part, open syllables, however, such as the languages of the Hmong-Mien family, nasal-liquid clusters only occur in syllable onset position. The 
syllable/morpheme in languages of this type is a 'front-loaded' $\mathrm{C}(\mathrm{C})(\mathrm{C}) \mathrm{V}(\mathrm{C})$ syllable, which historically results from a compression of disyllabic > 'sesquisyllabic' > monosyllabic forms (Ratliff 2015b). ${ }^{5}$ Although the nasal may have passed through a syllabic stage at one point in the development of this syllable type, in modern languages the nasal is not syllabic, and is best represented as a prenasalization feature. It is also not yet possible to reconstruct the earlier disyllabic and sesquisyllabic stages of the language (no first-syllable vowels are recoverable), so we must assume that Proto-Hmong-Mien also had complex onsets. Thus in order to find support for Ostapirat's reconstructions of *m.l(y)- and *m.r(y)- with subsequent stop epenthesis, we should look at the history of other languages of this type, ideally those not only with monosyllabic morphemes, but also, like HmongMien, with NCL- onsets and prenasalized stops, such as the languages of West Africa and other languages of Southeast Asia.

\section{$2.2 \quad$ NL-epenthesis in onset position}

Two potential parallels for epenthesis in an onset position have been brought to my attention. ${ }^{6}$ The first occurs in the Austronesian language Biak (=Numfor), spoken in Northwest New Guinea. Proto-CentralEastern Malayo-Polynesian *malip 'laugh; to laugh' becomes mbrif in Biak (Blust \& Trussel, n.d.). It is the only CEMP language to have developed a stop in this word, so the stop is clearly epenthetic. This is apparently a phonetic repair for an illegal onset cluster ml- which arose upon loss of the vowel in the first syllable. Van den Heuvel $(2006,54)$ also reports that the Biak verb 'to walk' mráne, is pronounced [mbráne]. It is not clear whether or not epenthetic stops are now stored as part of the lexical representation of all such words in Biak.

The second parallel occurs in the language Japhug, a Tibeto-Burman language of the Rgyalrongic subgroup. Jacques (2004) reconstructs both *NCL- and *NL- clusters for Proto-Rgyalrongic. Epenthetic stops develop in languages for which NL- is an impossible onset. There has thus been a merger of the reflexes of * NCL- and * NL- in some languages: "In Japhug it is very clear that mbr- has at least two origins, *mr- (as in mbro 'horse') and *mbr- $<{ }^{*} \mathrm{~N}-$ pr- (as in $m b r r t$ 'be cut', the anticausative

\footnotetext{
${ }^{5}$ Since a nasal is a possible coda-most frequently $-\eta \mathrm{n}$ in Hmongic; $-\mathrm{m}$, $-\mathrm{n}$, or $-\mathrm{n}$ in Mienic-clusters do occasionally arise between words in compounds, but such compounds cannot be reconstructed for the protolanguage, and are not relevant to the choice between the two reconstructions under consideration here.

${ }^{6}$ I am grateful to Emily Glasser and Guillaume Jacques for giving me information about Biak and Japhug, respectively.
} 
of prrt 'cut')" (Jacques, p.c.). The Japhug case is somewhat different from the Hmong-Mien case, however, because native *NL- words never show epenthetic stops in daughter languages (see section 4.3, below). But a merger of this type might help explain the Hmong-Mien form of some Chinese loanwords (see section 5).

\section{Arguments for an epenthesis rule in Hmong-Mien}

Epenthesis of a stop between a nasal and a liquid is attested in a variety of languages, and since epenthesis involves a natural process of feature spreading and phonetic accommodation, it can occur as a regular, albeit relatively rare, sound change.

Epenthesis has also occurred within onsets in typologically similar languages; there is precedent for reconstructing such correspondences as *m.l- and *m.r-.

Finally, since the usual direction of loanword flow is from Chinese to Hmong-Mien rather than from Hmong-Mien to Chinese (see for example Downer 1973, Ratliff 2009), Chinese/HM lookalikes are most likely to have been Chinese in origin. Given that there is no evidence of a stop in the correspondence sets for which Old Chinese *m.l- was reconstructed, it is not unreasonable to think that Hmong-Mien speakers introduced the stop when borrowing these words.

\section{Arguments against an epenthesis rule in Hmong-Mien}

\subsection{Laryngeal contrasts in the stop}

One of the strongest arguments against a regular epenthesis rule for Hmong-Mien is the fact that laryngeal contrasts must be reconstructed for the stops in this position: voiced, voiceless, and voiceless aspirated. If these stops arose by epenthesis we would expect to find only voiced stops here, given that the preceding and following consonants are both voiced (Picard's Rule I).

Most Hmong-Mien languages have merged voiced and voiceless stops in the daughter languages. However, the contrast is easily recoverable because the original contrast in the stops was transphonologized into a tonal register contrast which split the original four tones into eight: the original voiceless consonants yielded a higher variant and the original voiced consonants a lower variant of each original tone. Since tonal categories are quite stable across languages of

7 Both Ratliff and Ostapirat rely on Baxter \& Sagart (2014) for Old Chinese reconstructions. 
the family, these tone splits can be 'rolled back' and the original voicing contrast can be uncovered. This is true of Chinese, Vietnamese, and TaiKadai languages as well as Hmong-Mien languages (Ratliff 2015a).

A few Hmong-Mien languages did not undergo the tone split, however, and in these cases we can still see the contrast between voiced and voiceless stops between a nasal and a liquid. For example, in A-Hmø (Luobohe Miao) we find the minimal pairs given in (3) (Taguchi 2008).

\section{(3) $\mathrm{Nblo}^{\mathrm{A}}$ 'glutinous rice' vs. $\mathrm{Nplo}^{\mathrm{A}}$ 'to whip; a whip' NbloN $^{A}$ 'leaf' $\quad$ vs. NploN ${ }^{A}$ 'to rot'}

It is necessary to reconstruct voiceless aspirated stops in this position as well. Proto-Hmongic ${ }^{*} \mathrm{nt}^{\mathrm{h}}{ }^{\mathrm{r}} \mathrm{j} \mathrm{n}^{\mathrm{A}}$ 'puttees (leg wraps)' and ${ }^{*} \mathrm{mp} \mathrm{p}^{\mathrm{h}} \mathrm{l} \mathrm{e}^{\mathrm{A}}$ 'finger ring' are culturally important words with no identifiable external source. Proto-Hmongic may serve as a proxy for Proto-HmongMien because native words were frequently replaced by Chinese loanwords in Mienic; these words are thus arguably old.

Needless to say, a contrast between voiced, voiceless, and voiceless aspirated in the frame N_L is difficult to explain under the theory that all stops between a nasal and a liquid arose by a regular rule of epenthesis in Hmong-Mien.

\subsection{NCLs and NCs}

Another strong argument against the epenthesis analysis comes from a consideration of the place of NCL- onsets within the structure of the onset inventory of the protolanguage. Prenasalized stops are a hallmark feature of the Southeast Asian linguistic area (Ratliff 2015b). West and North Hmongic languages preserve prenasalized stop and affricate onsets at the labial, alveolar, retroflex $\left(<{ }^{*} \mathrm{NCr}-\right)$, palatal, velar, and uvular places of articulation. In East Hmongic languages and in Mienic languages they simplify to either nasals or stops according to the pattern in (4).
(4)
${ }^{*} \mathrm{NC}>\mathrm{NC}$
$* \mathrm{NC}_{[\text {-voice] }}>\mathrm{NC}$
${ }^{*} \mathrm{NC}_{[\text {-voice }]}>\mathrm{C}_{[\text {-voice }]}$
$* \mathrm{NC}_{[+ \text {voice] }}>\mathrm{N}$
West Hmongic languages
$* \mathrm{NC}>\mathrm{C}_{[+ \text {voice }]}$
North Hmongic languages
East Hmongic languages
North and East Hmongic languages
All Mienic languages

All reconstructions of the protolanguage to date include a rich set of prenasalized voiceless, voiceless aspirated, and voiced stops and 
affricates (Purnell 1970, Chang 1976, Downer 1982, Wang \& Mao 1995, Ratliff 2010).

Given this fact about Hmong-Mien onsets, the most parsimonious analysis of NCL- onsets is that they are combinations of prenasalized stops and liquids, an analysis made more likely since they occur at multiple places of articulation, as in (5), almost mirroring the distribution of prenasalized stops (for the reconstructed forms, see Ratliff 2010). ${ }^{8}$

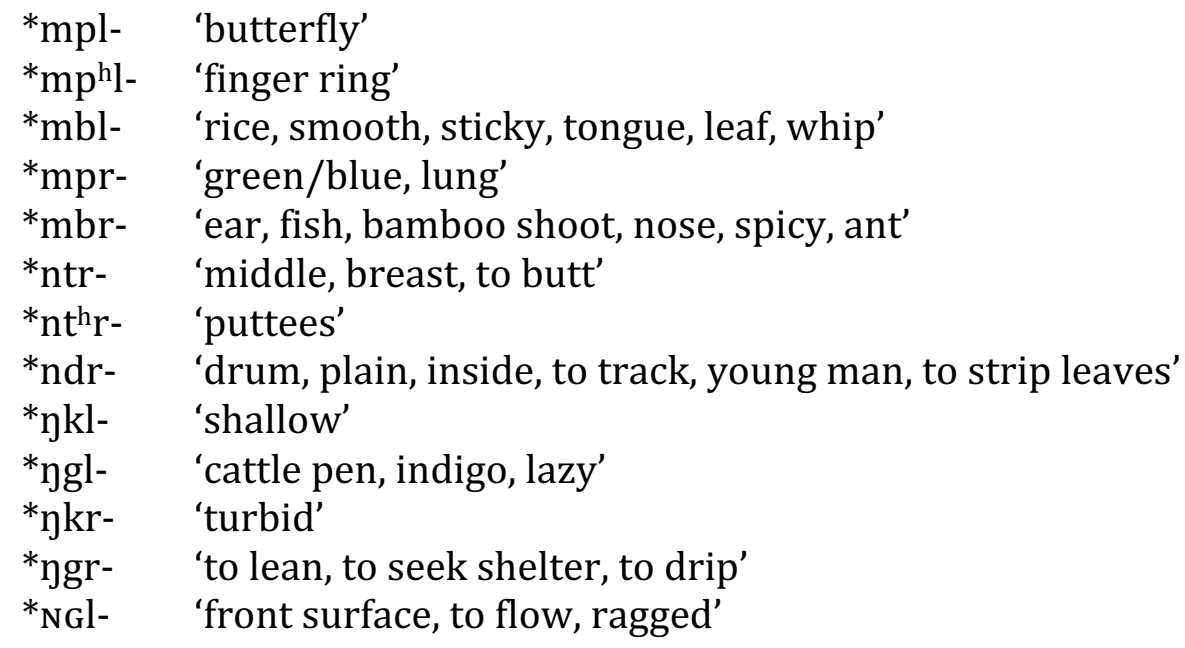

Furthermore, Picard's Rule I requires that the place of articulation of the epenthetic stop agree with the place of articulation of the consonant to its left. An analysis that holds that all of these clusters arose by epenthesis would thus require the reconstruction of a contrastive set of nasals ${ }^{*} \mathrm{~m}-,{ }^{*} \mathrm{n}-,{ }^{*} \mathrm{n}-$, and ${ }^{*}{ }_{\mathrm{N}}$ - before ${ }^{*}$-l- and ${ }^{*}$-r-, which seems highly unlikely.

\subsection{Exceptions}

A secondary argument against a regular rule of epenthesis for HmongMien is the existence of a number of words with NL- onsets in the protolanguage. ' If epenthesis had operated without exception whenever the right conditions for epenthesis were met, we would not expect to encounter forms such as Proto-Hmong-Mien *mlun ${ }^{*} \mathrm{jH}$ 'soft' and

\footnotetext{
8 The reconstruction of the clusters involving dorsals is quite difficult; some question the need to reconstruct both velars and uvulars as I have done.

9 There are also ml- onsets in modern-day languages such as White Hmong /mlua ${ }^{4 / 7}$ / 'weak', /mlua ${ }^{3}$ ' 'dented' and / $\mathrm{mlo}^{8} /$ 'idol', but of course one could say that the epenthesis rule had run its course before these words entered the language.
} 
*s-mrusyn 'to listen'. These *NL- words preserve a liquid in only one or two daughter languages; in most languages, the onsets simplify to a nasal, or a nasal plus a glide. In no language is a stop inserted between the nasal and liquid. Of course, the strength of the comparative method is that it highlights such exceptions so that researchers can look for explanations for them, such as phonological conditioning factors or the operation of later rules that have obscured the regularity of the earlier rule.

On a related note, given the typological similarity of languages in this area, it is interesting, if not conclusive one way or another, to note that historical linguists who have reconstructed ${ }^{*}$ NL- onsets for other Asian language families, with the exception of Jacques for Rgyalrongic and Ostapirat for Hmong-Mien, do not posit a regular rule of epenthesis for NL- onsets because stops do not appear between the nasal and the liquid in the daughter languages. This is the case for Baxter \& Sagart's Old Chinese *m(.)l- (2014), Matisoff's Proto-Tibeto-Burman *m(-)l- and *mr- $(2003,80-82)$, and Ostapirat's Proto-Kra *m-l- and *m-r- (2000, $213,215)$. For Proto-Kra correspondences in which the daughters show a stop, Ostapirat reconstructs *m-pl- and *m-bl-. ${ }^{10}$

\subsection{The loanword evidence reconsidered}

\subsection{1 'rice plant/unhusked rice'}

Old Chinese 稻 *[l] ${ }^{\text {'u}}$ ? 'rice; paddy' > Mandarin dào may be a loanword from Hmong-Mien *mbleu 'rice plant; unhusked rice'. If true, the word would have gone against the strong current of loanword flow between the two families; we are right to be skeptical about such a claim. But the archaeological record shows that rice cultivation occurred in the south before it was known to the ancient Chinese, who cultivated millet, and that the ancestors of the Hmong-Mien people were in the right location to have been the first rice cultivators: "... of the southern Chinese and Southeast Asian families extant today, the HM family is the one most likely to have originated closest to the central Yangzi early rice zone" (Bellwood 2005, 24, see also Sagart 2011, Blench 2005). This was one of a set of agricultural terms that Haudricourt \& Strecker (1991) argued gives evidence for a Hmong-Mien substratum in Chinese. Note that there is no evidence of an initial nasal in the Old Chinese word, although Sagart mentions that one possible source of Old Chinese ${ }^{*} \mathrm{I}^{\mathrm{S}}$ - is ${ }^{*} \mathrm{~m} . \mathrm{I}^{\mathrm{S}_{-}}$

10 Norquest (2015:90) reconstructs *ml- for Proto-Hlai when onsets in daughter languages show pl- (with unattested intermediate stages *mbl- $>*$ bl-), but in this case there is no evidence for the nasal, and others reconstruct a simple *pl-. 
(Sagart 2011, 128). Furthermore, the word does not appear in TibetoBurman (with the possible exception of Proto-Tamang *mla 'unhusked rice'), so cannot be reconstructed to Proto-Sino-Tibetan.

Determining direction of borrowing in this case is a very difficult matter. L. Sagart has changed his mind on the question over the years, which I take as a laudable willingness to remain open to new evidence. In 1995, in a response to Haudricourt \& Strecker (1991), he conceded that 'rice', unlike the other Chinese words for which a Hmong-Mien source had been proposed, may indeed have been a very early loan to Chinese from Hmong-Mien (Sagart 1995, 337). Then in 1999 and 2003, he noted problems with the onset, rime, and tone correspondences and concluded that the resemblance between the words was merely superficial (Sagart 1999, 182, Sagart 2003, 129). Finally, in 2011 he concluded that the word was a loan from Chinese to Hmong-Mien on semantic grounds: HmongMien shows the meaning 'rice plant/unhusked rice' and 'rice plant' is a secondary meaning in Chinese, the original meaning being the narrower 'dehusked rice grains out of the mortar', determined on the basis of graphic evidence (Sagart 2011, 128).

However, since this may have been a Hmong-Mien word, we must allow the possibility that the stop was part of the original root, and was dropped along with the initial nasal when it was borrowed by speakers of Old Chinese: *mbl- > *l-. This seems at least as likely as the possibility that the stop was introduced by epenthesis.

\subsection{2 'glutinous rice/millet'}

Finally, 'glutinous rice/millet' is an important areal word shared by Chinese, Hmong-Mien, and Malayo-Polynesian. It does not appear in Tibeto-Burman, so it is not reconstructable to Sino-Tibetan and it does not appear in the Formosan languages, so it is not reconstructable to Austronesian. Whose word it was originally is impossible to determine, but given the specificity of the phonological and semantic match, it clearly appears to be the same word, given the forms in (6) (reconstructions by Baxter \& Sagart 2014, Ratliff 2010, Blust \& Trussel, n.d.).

(6) Old Chinese

P-Hmong-Mien

P-Malayo-Polynesian *m(ə).lut 'glutinous millet'

*mblut 'glutinous, sticky; glutinous rice'

*pulut 'sticky sap' (Malay and other WMP: 'glutinous rice')

Since a stop appears in the Malayo-Polynesian word, and a loan from Chinese through small and land-locked Hmong-Mien, where it 
acquired a stop by epenthesis, and then on to enormous MalayoPolynesian seems highly unlikely, it makes much more sense to believe that this word always contained a bilabial stop.

\section{Conclusion}

Epenthesis of a stop between two consonants, in this case between a nasal and a liquid, is a natural process involving the timing of articulatory gestures, contrast enhancement, and feature-spreading. It can occur as a regular sound change, even though it is not a particularly common one. As in all reconstruction work, however, the decision about whether to reconstruct a simple cluster and an insertion rule or a more complex cluster and various deletion/simplification rules is dependent not only on the naturalness of the change and whether or not (and how widely) it has been attested elsewhere, but also on how the solution for the correspondence set in question fits within a network of other correspondences. In the Hmong-Mien case, a deletion account best accords with other properties of the Proto-Hmong-Mien onset inventory. The mbl- and mbr- onset correspondence sets cannot be analyzed in isolation.

I concede, however, that Proto-Hmong-Mien *mblet 'tongue' is a loanword from Old Chinese *mə.lat (舌 shé), and epenthesis probably does account for the stop in this word. This would have been a natural accommodation to the pre-existing series of NCL- clusters in the protolanguage, and would have occurred at the moment of borrowing within the protolanguage: the reconstruction should therefore still include a stop. The key transition would have been from the production to the perception and phonologization of a stop in this position. Kiparsky gives the following explanation about when phonologization is most likely to occur (Kiparsky 2003, 328).

The key generalization seems to be that phonologization will result more readily if the feature is of a type which already exists in the language. We would call this the priming effect and provisionally formulate it as follows:... Redundant features are likely to be phonologized if the language's phonological representations have a class node to host them.

Such an accommodation to a pre-existing native pattern would have occurred sporadically: it does not support the claim that a regular rule of epenthesis gave rise to the NCL- onsets of Hmong-Mien. 


\section{Comments invited}

PiHPh relies on post-publication review of the papers that it publishes. If you have any comments on this piece, please add them to its comments site. You are encouraged to consult this site after reading the paper, as there may be comments from other readers there, and replies from the author. This paper's site is here:

http://dx.doi.org/10.2218/pihph.3.2018.2877

\section{Acknowledgments}

I gratefully acknowledge stimulating discussion with the participants of the Third Edinburgh Symposium on Historical Phonology and the 17th Spring Workshop on Theory and Method in Linguistic Reconstruction, and thank the following people for giving me ideas and references: Henning Andersen, Alex François, Emily Gasser, Nathan Hill, Daniel Jacob, Guillaume Jacques, Haiyong Liu, Patrick Mächler, Geoff Nathan, Marc Picard, Paolo Ramat, Matthieu Segui, Lameen Souag, Peter Staroverov, and Jess Tauber.

\section{Author contact details}

Martha Ratliff

802 S. Seventh St.

Ann Arbor, Michigan 48103

U.S.A.

ac6000@wayne.edu

\section{References}

Baxter, William H. \& Laurent Sagart. 2014. Old Chinese: a new reconstruction. Oxford: Oxford University Press.

Bellwood, Peter. 2005. Examining the farming/language dispersal hypothesis in the East Asian context. In Laurent Sagart, Roger Blench \& Alicia Sanchez-Mazas (eds.), The peopling of East Asia, 1730. London: Routledge Curzon.

Blench, Roger. 2005. From the mountains to the valleys: understanding ethnolinguistic geography in Southeast Asia. In Laurent Sagart, Roger Blench \& Alicia Sanchez-Mazas (eds.), The peopling of East Asia, 31-50. London: Routledge Curzon.

Blust, Robert \& Stephen Trussel. n.d. The Austronesian Comparative Dictionary, web edition. http://www.trussel2.com/acd/ 
Chang, Kun. 1976. Proto-Miao initials. Bulletin of the Institute of History and Philology 47. 155-218.

Chen Qiguang. 2013. Miao-Yao yuwen [Miao and Yao Language]. Beijing: Zhongyang Minzu Daxue Chubanshe.

Downer, Gordon B. 1973. Strata of Chinese loanwords in the Mien dialect of Yao. Asia Major 18(1). 1-33.

Downer, Gordon B. 1982. Problems in the reconstruction of Proto-MiaoYao. Paper presented at the 15th International Conference on SinoTibetan Languages and Linguistics, Beijing.

Haudricourt, André G. \& David Strecker. 1991. Hmong-Mien (Miao-Yao) loans in Chinese. T'oung Pao 77(4-5). 335-341.

Jacques, Guillaume. 2004. Phonologie et morphologie du Japhug (rGyalrong). Paris: Université Paris dissertation.

Kiparsky, Paul. 2003. The phonological basis of sound change. In Brian D. Joseph \& Richard D. Janda (eds.), The handbook of historical linguistics, 313-342. Malden, MA: Blackwell.

Matisoff, James A. 2003. Handbook of Proto-Tibeto-Burman. Berkeley: University of California Press.

Norquest, Peter K. 2015. A phonological reconstruction of Proto-Hlai. Leiden: Brill.

Ohala, John J. 1997. Emergent stops. Proceedings of the $4^{\text {th }}$ Seoul International Conference on Linguistics, 84-91.

Ostapirat, Weera. 2000. Proto-Kra. Linguistics of the Tibeto-Burman Area 23(1). 1-251.

Ostapirat, Weera. 2016. Issues in the reconstruction and affiliation of Proto-Miao-Yao. Language and Linguistics 17(1). 133-145.

Picard, Marc. 1987. On the general properties of consonant epenthesis. Canadian Journal of Linguistics 32(2). 133-142.

Picard, Marc. 1989. Consonant epenthesis as a regular sound change. Diachronica 6(2). 223-236.

Purnell, Herbert C., Jr. 1970. Toward a reconstruction of Proto-Miao-Yao. Ithaca, NY: Cornell University dissertation.

Ratliff, Martha. 2009. Loanwords in White Hmong. In Martin Haspelmath \& Uri Tadmor (eds.), Loanwords in the world's languages: a comparative handbook, 638-658. Berlin: DeGruyter Mouton.

Ratliff, Martha. 2010. Hmong-Mien language history. Canberra: Pacific Linguistics.

Ratliff, Martha. 2015a. Tonoexodus, tonogenesis, and tone change. In ed. Patrick Honeybone \& Joseph Salmons (eds.), The Oxford handbook of historical phonology, 245-261. Oxford: Oxford University Press.

Ratliff, Martha. 2015b. Word-initial prenasalization in Southeast Asia: a historical perspective. In N. J. Enfield \& Bernard Comrie (eds.), The 
languages of mainland Southeast Asia: the state of the art, 31-50. Berlin: deGruyter.

Recasens, Daniel. 2011. Articulatory constraints on stop insertion in consonant clusters. Linguistics 49(5). 1137-1162.

Sagart, Laurent. 1995. Chinese 'buy' and 'sell' and the direction of borrowings between Chinese and Hmong-Mien: a response to Haudricourt and Strecker. T'oung Pao 81(4-5). 328-342.

Sagart, Laurent. 1999. The roots of Old Chinese. Amsterdam: John Benjamins.

Sagart, Laurent. 2003. The vocabulary of cereal cultivation and the phylogeny of East Asian languages. Indo-Pacific Prehistory Association Bulletin 23.127-136.

Sagart, Laurent. 2011. How many independent rice vocabularies in Asia? Rice 4(4). 121-133.

Taguchi, Yoshihisa. 2008. A vocabulary of Luobohe Miao. Tokyo: CbLLE Press.

van den Heuvel, Wilco. 2006. Biak: description of an Austronesian language of Papua. Amsterdam: Vrije Universiteit dissertation.

Wang, Fushi \& Zongwu Mao. 1995. Miáoyáoyǔ gǔyīn gòuň̌ [Reconstruction of the sound system of proto-Miao-Yao]. Beijing: Zhōngguó shèhuì kēxué chūbănshè [China Social Sciences Press].

Warner, Natasha \& Andrea Weber. 2001. Perception of epenthetic stops. Journal of Phonetics 29. 53-87. 